\title{
Biochemical and Histological Studies of Goji Extract Role on Patulin Mycotoxin on Male Rat Kidney
}

\author{
Nagwa M. El-Sawi ${ }^{1 *}$, Madeha N.Al-Seni ${ }^{2}$, Nesreen G.Abd El Haliem ${ }^{3}$, Mohamed T. El-Wassimy ${ }^{1}$, \\ H.Salah ${ }^{1}$, Asma S.Abdo ${ }^{1}$
}

${ }^{1}$ Department of Chemistry, Faculty of science, Sohag University, Sohag, Egypt

${ }^{2}$ Department of Biochemistry, Faculty of Science, King Abdulaziz University, Jeddah, KS A

${ }^{3}$ Department of Histology, Faculty of Medicine, Sohag Univerisity, Sohag, Egypt

*Corresponding Author: Nagwa M. Elsawi, Department of Chemistry, Faculty of Science, Sohag University, Sohag, Egypt.

E-mail: elsawinagwa@yahoo.com

\begin{abstract}
Patulin caused severe damage in several organ systems like kidney, intestinal tissue and immune system. The objective of this study is to show the effects of patulin mycotoxin on some biochemical parameters and histological changes on male rats' kidney. 50 adult albino male rats were divided randomly into 5 groups. Control group was injected subcutaneously daily with distilled water; groups I and II were injected subcutaneously daily with Patulin $(0.2 \mathrm{mg} / \mathrm{kg} / \mathrm{day})$ for one and two weeks respectively. Group III was treated with the same dose of patulin for two weeks after that they were injected subcutaneously with Goji extract $(2 \mathrm{ml} /$ $\mathrm{kg} /$ day) for two weeks. Group IV was treated by Goji for two weeks after that they were treated with the same dose of patulin for two weeks. Level of total antioxidant stress (TAS), Blood urea nitrogen (BUN) and pyruvate kinase (M2-PK) were decreased significantly in serum of both treated groups compared with control group, but level of serum creatinine (SCr), Alpha feto protein (AFP) and carcinoembryonic antigen (CEA) were increased significantly in serum of both treated groups compared with control group. Histopathological changes of rat kidney coincided with biochemical changes. In conclusion, consumption of patulin induced renal toxicity. Goji extract may be used as a new therapeutic for patulin toxicity.
\end{abstract}

Received Date: August 21, 2015

Accepted Date: October 29, 2015

Published Date: November 04, 2015

Citation: Nagwa, M. E., et al. Biochemical and Histological Studies of Goji Extract Role on Patulin Mycotoxin on Male Rat Kidney. (2015) Int J Food Nutr Sci 2(2): $122-128$.

DOI: $10.15436 / 2377-0619.15 .036$

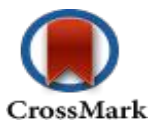

Keywords: Mycotoxin, Patulin, Kidney, Rat, Goji extract, Ultrastructure

\section{Introduction}

Toxins produced by filamentous fungi are called mycotoxins. This term, by general consensus, is used almost exclusively for fungi associated with food products and animal feed, excluding toxins produced by mushrooms ${ }^{[1]}$. Mycotoxins are secondary metabolites, with no apparent function in the normal metabolism of fungi. They are produced mainly, although out exclusively, when the fungus reaches maturity ${ }^{[2]}$. Mycotoxins commonly occur in human and animal food derivatives and can appear in the field before harvest, post-harvest or during processing, storage and feeding, adversely affecting the quality of the food ${ }^{[3]}$.

Patulin (Figure A), is an unsaturated heterocyclic lactone produced by certain fungal species of Penicillium, Aspergillus and Byssochlamys growing on fruit ${ }^{[4]}$. Patulin has been mainly found in apple and apple products and occasionally in pears, grapes, apricots, strawberries, blueberries and peaches ${ }^{[5]}$. Animal tissues affected by PAT administration included kidney and intestine ${ }^{[6,7]}$. PAT is believed to exert its cytotoxic effects mainly by forming covalent adducts with essential cellular thiols in proteins and amino acids ${ }^{[8]}$. The sub-acute administration of patulin has been mainly studied in rats, where it was shown to induce weight loss, gastric and intestinal changes and alterations in renal function ${ }^{[9]}$. Repetitive doses lead to signs of neurotoxicity (tremors, convulsions) as well as an inhibition of several enzymes (ATPase) in the intestine ${ }^{[10]}$, and the brain, in particular, with consequences in terms of lipid 
metabolism $^{[11]}$<smiles>O=C1C=C2C(=CCOC2O)O1</smiles>

Figure A: Structure of patulin (PAT)

Fresh extracts of fruits, herbs, vegetables, cereals and other plant materials rich in phenolics are of increasing interest in the food industry, because they retard oxidative degradation of lipids and thereby improve the quality and nutritive value offood $^{[12]}$. Lyciumbarbarum (Goji) (Figure b) have been used in Chinese medicine for over 2000 years where their beneficial effects are claimed to enhance the immune system, improve eye sight, and circulation, and to possess anticarcinogenic properties. The immune enhancing, anti-cancer and antioxidative properties of Wolfberry polysaccharides are reported in several Chinese publications ${ }^{[13,14]}$.

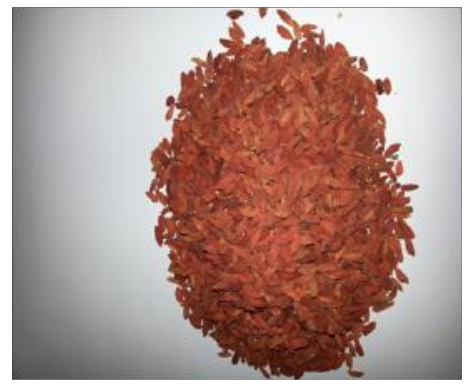

Figure b: The fruit of LyciumBarbarum (Goji)

The present study was planned to assess the biochemical profile supported by histological evidence of patulin on kidney of male rat in order to evaluate the possible role of Goji extract in reversing patulin toxicity.

\section{Materials and Methods}

\section{Chemicals}

Patulin (4-hydroxy-4H-furo [3, 2-c] pyran-2 (6H)-one) was obtained from Sigma Chemical Company.

\section{Extraction of Goji}

Goji berry extract was made according to Yang and Baojun 2013 ${ }^{[15]}$.

\section{Experimental Design and Animals}

Fifty white male albino rats each weighs (240-300 g) were kept at $22^{\circ} \mathrm{C}$, and $12 \mathrm{~h}$ light and $12 \mathrm{~h}$ dark cycle. They were given standard rat diet and had free access to tap water. The animals were divided randomly into five groups (10 rats each in two cages) and were subjected to the following schedule of treatments:

Control group was injected subcutaneously daily with distilled water; groups I \& II were injected subcutaneously daily with patulin $0.2 \mathrm{mg} / \mathrm{kg} /$ day $^{[16]}$ for one and two weeks respectively. Group III was treated by patulin as previous dose for two weeks after that they were injected subcutaneously with Goji extract $2 \mathrm{ml} / \mathrm{kg}$ /day for two weeks. Group IV was treated by Goji for two weeks after that they were injected subcutaneously with the same toxin for two weeks.

\section{Biochemical Studies}

Animals were anesthetized under light diethyl ether and blood samples were collected from the heart into plain tubes and stored at $-20^{\circ} \mathrm{C}$ until analysis was performed. Sera were used for the measurement of Blood Urea Nitrogen (BUN), Serum Creatinine ( $\mathrm{SCr}$ ), total antioxidant stress (TAS), Alpha feto protein (AFP), Carcinoembryonic Antigen (CEA) and Pyruvate Kinase (M2-PK). Level of (BUN) was measured according to Urease-Berthelot method. Level of ( $\mathrm{SCr}$ ) was measured by Jaffe Reaction. In addition, (TAS) concentration was measured by reaction of antioxidants in the sample with a defined amount of hydrogen peroxide $\left(\mathrm{H}_{2} \mathrm{O}_{2}\right)$; the antioxidants in the sample eliminate a certain amount of the hydrogen peroxide. The residual $\mathrm{H}_{2} \mathrm{O}_{2}$ is determined colorimetrically by an enzymatic reaction which involves of 3,5, dichloro-2-hydroxybenzensulphonate to a colored product. (AFP) and (CEA) were determined by ELISA kit was purchased from Elab Science. (M2-PK) was determined by ELISA kit was purchased from Wkeamed supplies.

\section{Histological Studies}

For the histological preparations, the abdomen was opened and dissected to remove their right and left kidneys at the end of the treatment. Renal tissues were cut into small pieces and then fixed in $10 \%$ neutral buffered formalin for $24 \mathrm{~h}$ and $4 \%$ glutaraldehyde for light and electron microscope ${ }^{[17,18]}$, examined and photographed using a JEOL JEM 1010 electron microscope (JEOL Ltd, Tokyo, Japan) in the Electron Microscope Research Laboratory of the Histology and Cell Biology Department, Faculty of Medicine, Sohag University (Egypt).

\section{Statistical Analysis}

Statistics was performed using the statistical graph pad prism 5. One way analysis of variables (ANOVA) was used posted by Newman-keuls test. All results are expressed as mean \pm $\mathrm{SE}$ and the level of significance between groups were $* \mathrm{p}<0.05$, $* * \mathrm{p}<0.01, * * * \mathrm{p}<0.0001$ (Table 1).

Table 1: Effect of Patulin $(0.2 \mathrm{mg} / \mathrm{Kg}$ b. w. $)$ on Some Biochemical Parameters of Male Rats:

\begin{tabular}{|c|c|c|c|c|c|}
\hline Groups & \multirow{2}{*}{ Control } & \multirow{2}{*}{ Group I } & \multirow{2}{*}{ Group II } & \multirow{2}{*}{ Group III } & \multirow{2}{*}{ Group IV } \\
\hline Parameters & & & & & \\
\hline $\begin{array}{l}\text { BUN ) } \\
\mathrm{mmol} / \mathrm{l})\end{array}$ & $\begin{array}{c}6.49 \pm \\
0.323\end{array}$ & $\begin{array}{l}5.023 \pm \\
0.2940^{* *}\end{array}$ & $\begin{array}{l}5.177 \pm \\
0.1607^{* *}\end{array}$ & $\begin{array}{l}6.462 \pm \\
0.18 \mathrm{n} . \mathrm{s}\end{array}$ & $\begin{array}{c}6.575 \pm \\
0.335 \text { n.s }\end{array}$ \\
\hline $\mathrm{SCr}(\mathrm{mg} / \mathrm{dl})$ & $\begin{array}{c}0.7303 \pm \\
0.03771\end{array}$ & $\begin{array}{c}1.312 \pm \\
0.1025^{* * *}\end{array}$ & $\begin{array}{l}1.105 \pm \\
0.1315^{\text {*** }}\end{array}$ & $\begin{array}{l}0.725 \pm \\
0.04 \text { n.s }\end{array}$ & $\begin{array}{c}0.847 \pm \\
0.0578 \text { n.s }\end{array}$ \\
\hline TAS $(\mathrm{m} \mu / 1)$ & $\begin{array}{l}2.128 \pm \\
0.07345\end{array}$ & $\begin{array}{c}1.54 \pm \\
0.05797^{* * *} \\
\end{array}$ & $\begin{array}{c}1.551 \pm \\
0.05405^{* * * *}\end{array}$ & $\begin{array}{c}2.48 \pm \\
0.025 \mathrm{n} . \mathrm{s}\end{array}$ & $\begin{array}{c}2.371 \pm \\
0.044 \text { n.s }\end{array}$ \\
\hline $\begin{array}{l}\text { M2-PK (ng/ } \\
\mathrm{ml})\end{array}$ & $\begin{array}{l}1.477 \pm \\
0.3354\end{array}$ & $\begin{array}{c}0.6449 \pm \\
0.1295^{*}\end{array}$ & $\begin{array}{c}0.7074 \pm \\
0.1226^{*}\end{array}$ & $\begin{array}{c}1.56 \pm \\
0.217 \text { n.s }\end{array}$ & $\begin{array}{c}1.37 \pm \\
0.164 \text { n.s }\end{array}$ \\
\hline $\begin{array}{l}\text { CEA (ng/ } \\
\mathrm{ml})\end{array}$ & $\begin{array}{c}0.06399 \pm \\
0.01747\end{array}$ & $\begin{array}{c}0.2473 \pm \\
0.06325^{* * *}\end{array}$ & $\begin{array}{l}0.1978 \pm \\
0.01715^{* *} \\
\end{array}$ & $\begin{array}{c}0.059 \pm \\
0.011 \mathrm{n} . \mathrm{s}\end{array}$ & $\begin{array}{l}0.1041 \pm \\
0.003 \mathrm{n} . \mathrm{s}\end{array}$ \\
\hline $\begin{array}{l}\mathrm{AFP}(\mathrm{ng} / \\
\mathrm{ml})\end{array}$ & $\begin{array}{c}0.375 \pm \\
0.012\end{array}$ & $\begin{array}{c}0.752 \pm \\
0.207^{*}\end{array}$ & $\begin{array}{l}0.918 \pm \\
0.164^{*}\end{array}$ & $\begin{array}{c}0.445 \pm \\
0.029 \text { n.s }\end{array}$ & $\begin{array}{c}0.586 \pm \\
0.066 \text { n.s }\end{array}$ \\
\hline
\end{tabular}

Data are expressed as mean $\pm \mathrm{SE}$. Number of sample in each group is 10 . G1, G2 = Treated group with Patulin.

Significant change in comparison between groups:

${ }^{*} \mathrm{p}<0.05 ; * * \mathrm{p}<0.01 ; * * * \mathrm{p}<0.001$ 
N.S Non significant $(\mathrm{P}>0.05)$

\section{Results}

\section{Biochemical Results \\ The Data in Table 1 Indicated That}

The mean value of serum BUN concentration $(\mathrm{mmol} / \mathrm{L})$ showed highly significant decrease $(P>0.01)$ in G I and G II as compared with control. The mean value of serum SCr concentration $(\mathrm{mg} / \mathrm{dl})$ showed highly significant increase $(\mathrm{P}>0.001)$ in $\mathrm{G}$ I and G II as compared with control. The mean value of serum TAS concentration $(\mathrm{m} \mu / \mathrm{l})$ showed highly significant decrease $(\mathrm{P}$ $>0.001)$ in G I and G II as compared with control. The mean value of serum AFP and CEA concentration $(\mathrm{ng} / \mathrm{ml})$ showed highly significant increase $(P>0.001)$ in $G$ I and $G$ II as compared with control .The mean value of serum M2-PK concentration $(\mathrm{ng} / \mathrm{ml})$ showed significant decrease $(\mathrm{P}>0.05)$ in $\mathrm{G} \mathrm{I}$ and G II as compared with control.However, Non-significant changes in the mean value of all previous biochemical parameters in G III and G IV were observed as compared to control.

\section{Histological Results}

In light microscopic examination the renal cortex of the control group was characterized by the presence of renal corpuscles, proximal and distal convoluted tubules (PCT\&DCT). Each renal corpuscle was consisted of a glomerular capillary tuft surrounded by capsular space and Bowman's capsule (Figure 1a). Ultrastructure, glomerular capillaries were lined by a thin layer of fenestrated endothelial cells and surrounded by podocytes's foot processes (Figure 1b). The PCT rested on a thin regular basement membrane and lined by cuboidal cells with profuse luminal microvilli. They had large rounded euchromatic nuclei with prominent nucleoli, many apical pinocytotic vesicles, lysosomes, basal infoldings and longitudinal arranged mitochondria (Figure 1c). The DCT had few irregular small luminal microvilli. Their cells contained large apical euchromatic nuclei and mitochondria in the basal infoldings (Figure 1d).
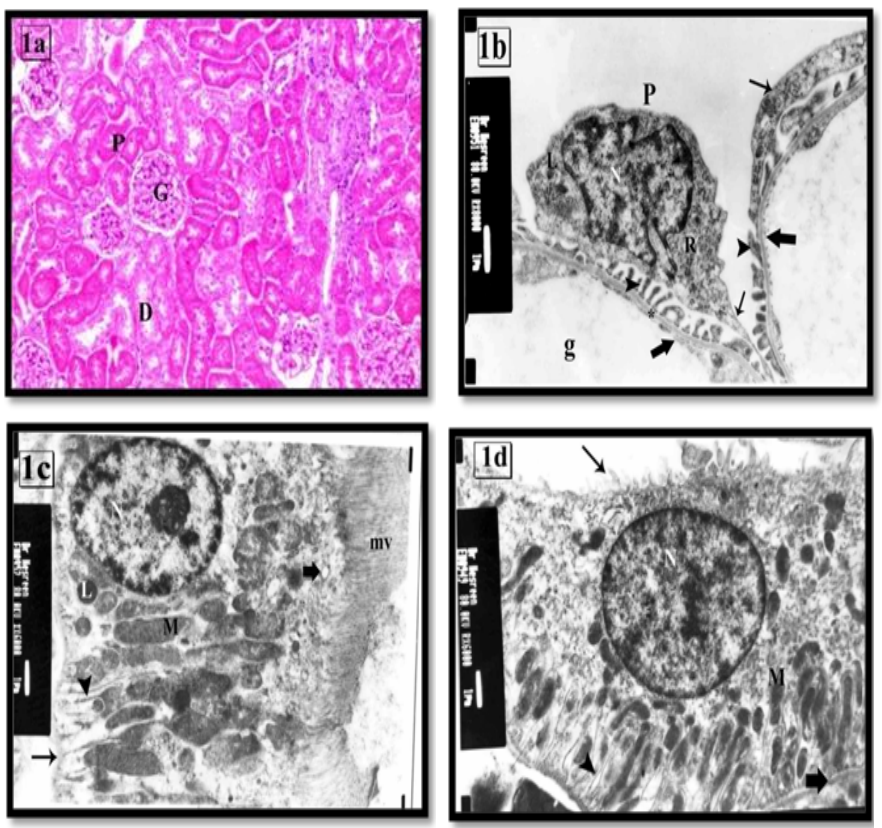

Figure 1 (a) the renal cortex of control group showing renal corpuscles have a glomerular tuft $(\mathrm{G})$ and urinary space (arrow). PCT (P) and
DCT (D) cells have acidophilic cytoplasm and rounded vesicular nuclei. $\mathrm{H} \& \mathrm{E} \times 100$

(b) The renal corpuscle of control group showing podocyte $(\mathrm{P})$, primary processes (thin arrow) and numerous foot processes (arrow head) rest on the glomerular basement membrane (asterisk). The cytoplasm contains irregular nucleus (N), RER (R) and lysosomes (L).Note: the fenestrated endothelium (thick arrow) of the glomerular capillaries ( $\mathrm{g}$ ). $\mathrm{X} 8000$

(c) A PCT lining cell of control group showing numerous long apical microvilli (mv) and regular thin basement membrane (arrow). The cytoplasm has euchromatic nucleus $(\mathrm{N})$ with prominent nucleolus, pinocytotic vesicles (thick arrow), basal infoldings (arrow head), mitochondria (M) and few lysosomes (L). X6000

(d) A DCT lining cell of control group showing apical euchromatic nucleus $(\mathrm{N})$, basal infoldings (arrow head) associated with elongated mitochondria (M), and a few luminal microvilli (thin arrow). Note: the regular thin basement membrane (thick arrow). X6000

The renal cortex of group I exhibited glomerular hyper cellularity, reduction of the urinary space and widening in the lumen of tubules. Many PCTs had destructed wall and cellular casts in their lumen. Mitotic figures and atypical nuclei were seen in some tubules. Interstitial inflammatory cellular infiltration was also observed (Figures 2a, 2b). Ultrastructure the podocytes had large lysosomes, vacuoles and fusion of some foot processes. The endothelial cell membrane exhibited beaded appearance (Figure 2c). Many of the PCTs cells had partial loss of their apical microvilli, thickening of the basement membrane, loss of the basal infoldings. Variable sized cytoplasmic vacuoles, primary and secondary lysosomes were also noticed (Figure 2d). Some cells revealed irregular heterochromatic nuclei, diffuse vacuolar degeneration with absence of apical microvilli (Figure2e). DCT cells exhibited some areas of rarified cytoplasm (Figure $2 \mathrm{f}$ ).
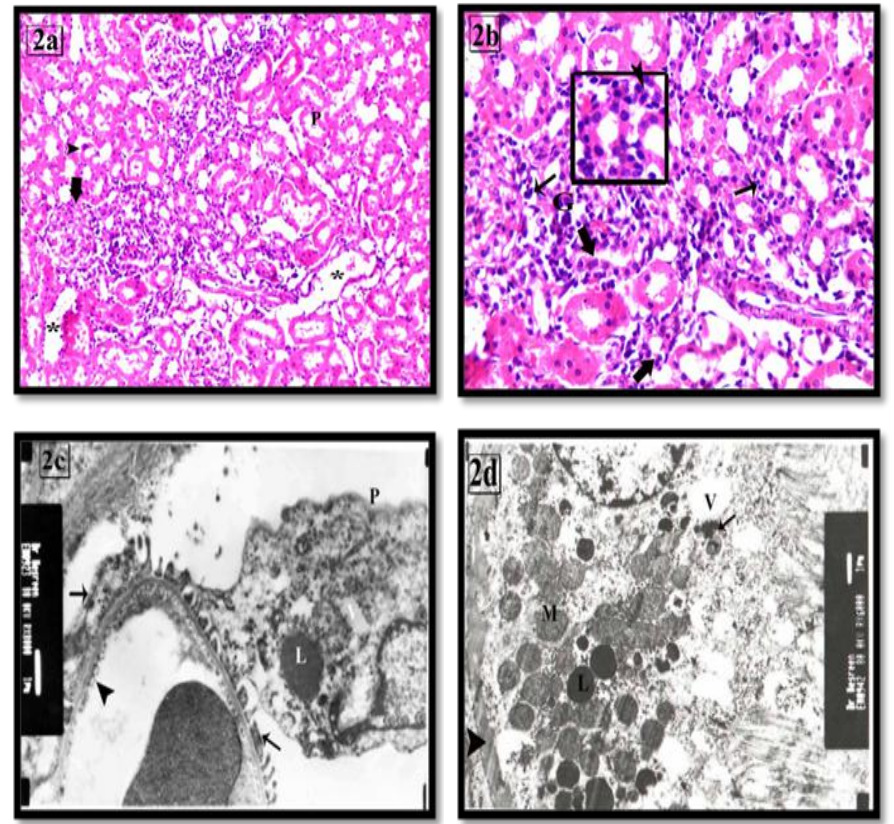

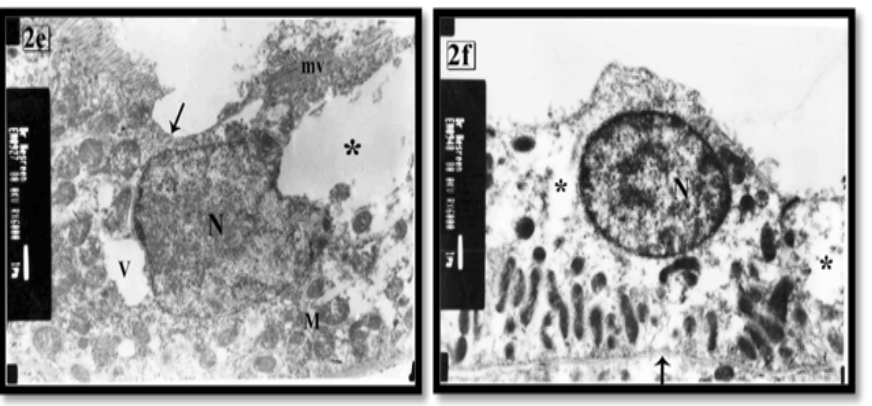

Figure 2: The renal cortex of group I showing (a) partial loss of the brush border of PCT (P). Some tubules have cellular cast (arrow head) and wide lumens $(*)$. The glomerular hypercellularity with obliteration of the urinary space is frequently seen (thick arrow). H\&E X100 (b) Interstitial inflammatory cellular infiltration (thin arrow) and foreign body giant cell $(\mathrm{G})$ are seen. Some tubules have mitotic figure (thick head). The inset shows atypical nuclei in the lining cells of renal tubule H\&E X200 inset X400.

(c) Segmental foot processes fusion (arrow) and beaded appearance of the endothelium are seen in some areas (arrow head). Cytoplasm of podocyte (P) contains vacuoles (V) and large primary lysosome (L) $\mathrm{X} 8000$

(d) A PCT lining cell has irregular thick basement membrane (arrow head), absence of the basal infoldings and destructed mitochondria (M). It contains primary (L) and secondary (arrow) lysosomes and vacuoles (V). (e) apoptoticchanges in some cells as irregular heterochromatic nucleus $(\mathrm{N})$, vacuoles $(\mathrm{V})$, no basal infoldings and loss of parallel arrangement of mitochondria (M). Microvilli are intact in some areas (mv) while absent in others $(\uparrow)$ with apical large vacuoles $(*)$ and massive loss of organelles. X6000

(f) A DCT lining cell has euchromatic nucleus (N), less apparent basal infoldings (arrow head). Some areas of rarified cytoplasm (asterisk) are noticed. Note thin basement membrane (arrow). X6000

The light microscopic examination of group II revealed persistence histological changes of the previous group with appearance of hyaline casts in the lumen of some tubules (Figure 3a). Ultrastructure, irregular thickened GBM and loss of endothelial fenestrae were seen (Figure 3b). The PCTs showed thickened basement membrane and destructed basal infoldings. Some cells revealed karyolitic nuclei, few mitochondria, numerous vacuoles and absence of luminal microvilli (Figure 3c). DCT cells exhibited heterochromatic irregular nuclei, apical migration of the mitochondria, numerous vacuoles and absence of apical microvilli (Figure 3d).
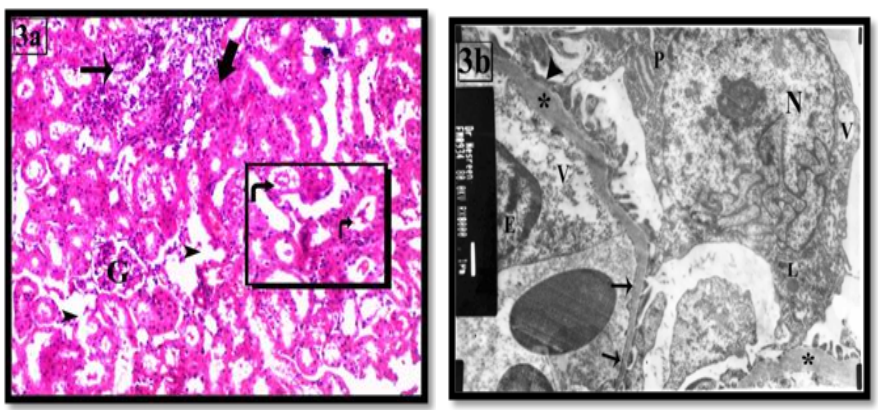
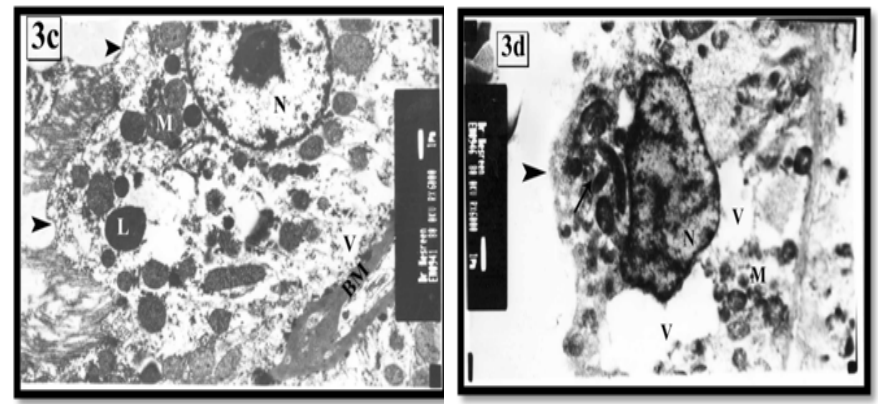

Figure 3: The renal cortex of group II showing (a) Glomerular shrinkage $(\mathrm{G})$ and focal area of inflammatory cellular infiltration (arrow). Some tubules have destructed wall (arrow head) and hyperplasia of epithelial lining of others (thick arrow) is also seen. Inset: shows cellular and hyaline casts in the lumen of some tubules (curved arrow). H\&E X100 \& inset X200

(b) Focal thickening of the GBM (*) and losing its trilaminar structure $\left.{ }^{*}\right)$ with segmental foot process fusion (arrow head) are seen. The endothelial cell (E) contains vacuoles (V) with focal loss of their fenestrae (arrow). The podocyte $(\mathrm{P})$ contains highly indented nucleus $(\mathrm{N})$, vacuoles (V) and lysosomes (L). X8000

(c) A PCT lining cell has thick basement membrane (BM), absence of luminal microvilli (arrow head) and destructed basal infoldings. Karyolitic nuclei $(\mathrm{N})$, apparent decrease of the mitochondria $(\mathrm{M})$, numerous vacuoles $(\mathrm{V})$ are seen in the cytoplasm. X6000

(d) apoptotic DCT lining cell has irregular heterochromatic nucleus (N) and apical aggregation of the organelles (arrow). The basal cytoplasm contains large vacuoles (V) and loss of the basal infoldings. Note: no apical microvilli are seen (arrow head). X6000

The therapeutic use of Goji group III led to decrease in the histological changes of the kidney. Most of the renal cortical tissues were more or less similar to the control group. Some tubules were lined with vacuolated cells. Others with dilated and destructed wall were still seen. Dilated congested blood capillaries were also observed (Figure 4a). On the other hand, the prophylactic use of goji group IV revealed marked improvement as compared with group III (Figure 5a). Ultrastructure podocytes, GBM and blood capillaries were more or less similar to the control group (Figures 4b,5b). Some PCT cells appeared with vacuolated cytoplasm (Figures 4c, 5c). Most of DCT cells were more or less similar to the control group (Figures $4 \mathrm{~d}, 5 \mathrm{~d}$ ).
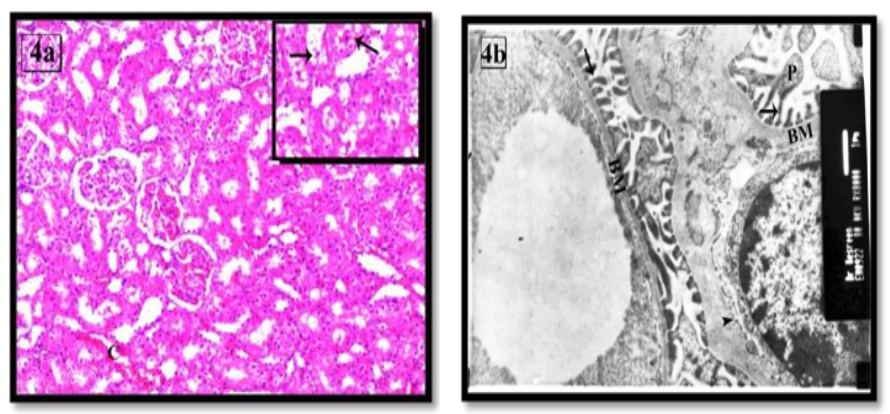


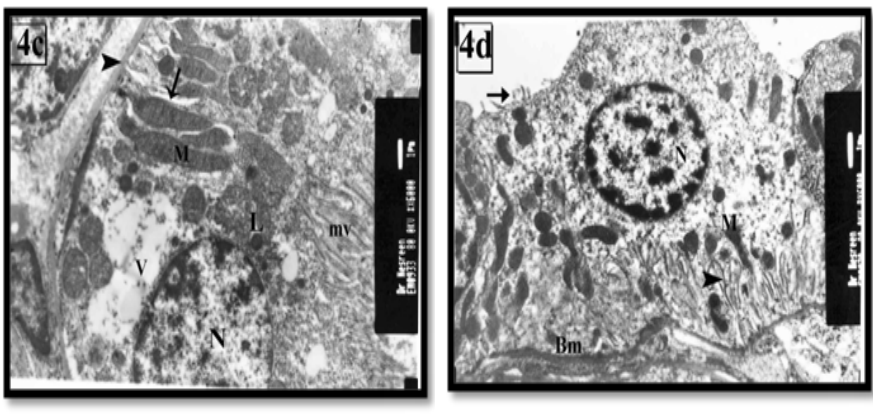

Figure 4: The renal cortex of group III showing (a) proximal and distal tubules are more or less similar to control. Dilated congested capillaries are also seen $(\mathrm{C})$. The inset shows desquamated cells and few cells with vacuolated cytoplasm (arrow). H\&E X100 \& inset X200

(b) GBM (BM), primary processes (P) and foot pedicle (arrow) are similar to the control. The fenestrated endothelial membrane (arrow head) is also seen. $\mathrm{X} 8000$

(c) Restoration of the long apical microvilli (mv) and the elongated basal mitochondria (M) within the basal infoldings (arrow) are seen in PCT ' cell. Its cytoplasm contains euchromatic nucleus (N), few lysosomes (L) and large vacuoles (V). Note: thin basement membrane (arrow head). X6000

(d) A DCT lining cell has euchromatic nuclei (N), few short apical microvilli (arrow) and elongated mitochondria (M) in-between basal infoldings (arrow head).Note: thin basement membrane (BM). X6000
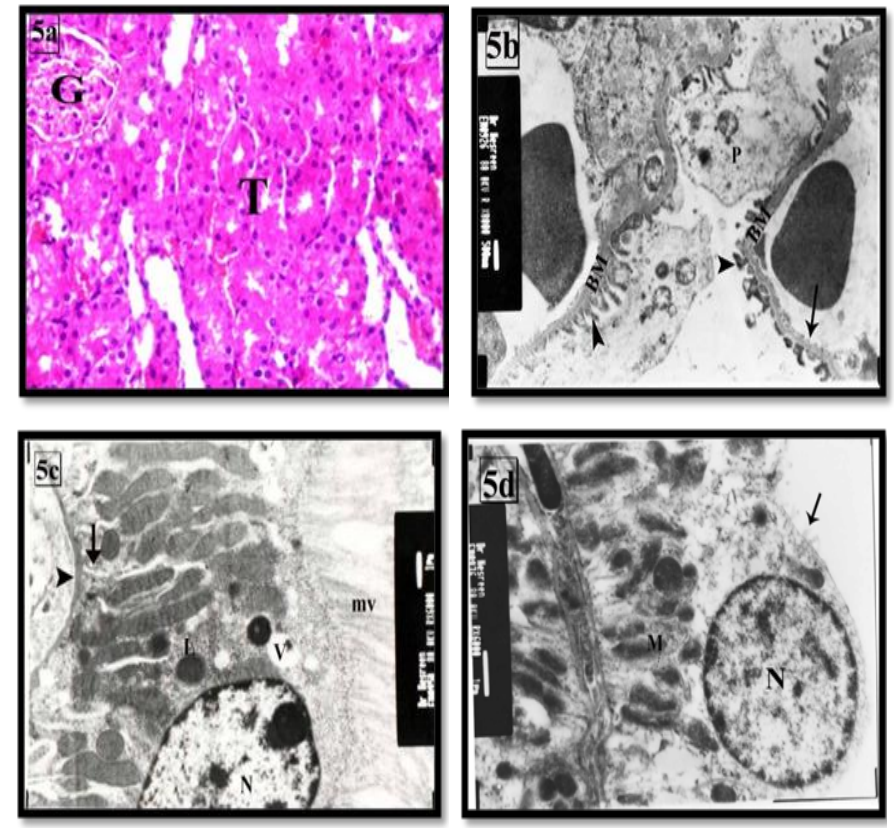

Figure 5: the renal cortex of group IV showing (a) most of the tubules $(\mathrm{T})$ and the renal glomeruli $(\mathrm{G})$ are more or less similar to control group. H\&EX400

(b) The fenestrated endothelium (arrow), primary (P) and foot pedicles (arrow head), and basement membrane $(*)$ are more or less similar to control. X8000

(c) A PCT lining cell is similar to control. It contains euchromatic nuclei $(\mathrm{N})$ and longitudinal arranged mitochondria $(\mathrm{M})$ within basal infoldings (arrow), lysosomes (L), apical microvilli (mv), thin basal lamina (arrow head) and apical vacuoles (V). X6000

(d) DCT lining cells are more or less similar to control. It contains euchromatic nucleus $(\mathrm{N})$, apical microvilli (arrow) and basal mitochondria (M) within the basal infoldings. X6000

\section{Discussion}

In the present investigation, the effect of patulin on BUN, SCr, TAS, AFP,CEA and M2-PK was studied in male albino rats.

The mean value of BUN concentration $(\mathrm{mmol} / \mathrm{L})$ showed highly significant decrease $(\mathrm{P}>0.01)$ in $\mathrm{G}$ I and G II. Urea is amajornitrogenous end product of protein and amino acid catabolism, produced by liver. In kidneys urea is filtered out of blood by glomerulli and is partially being reabsorbed with water ${ }^{[19]}$. these results may be attributed to the varying toxic effect of patulin on kidney function as indirect effect that the low value of urea could be referred to acute liver failure (decreased urea synthesis), and repeated peritoneal dialysis ${ }^{[20]}$ and also low levels of urea are seen in trauma, surgery, opioids, malnutrition, and anabolic steroid use ${ }^{[21]}$. Rats treated with patulin showed highly significant increase $(P>0.001)$ in the mean value in G I and G II. This increased level of SCr may be due to acute renal insufficiency ${ }^{[22]}$ and in most cases of mycotoxin nephrotoxicity ${ }^{[23]}$ and also the observed elevation in creatinine may be related to several factors controlling urea metabolism such as homeostasis of amino acids in the body, suppression of gluconeogenesis, presence of tissue damage and liver or kidney lesions. All these factors are proved to be affected by patulin as reported by ${ }^{[24,25]}$. In the current study, the mean value of serum TAS concentration $(\mathrm{m} \mu / \mathrm{l})$ showed highly significant decrease $(\mathrm{P}>0.001)$ in $\mathrm{G}$ I and G II, this was most probably point to presence of an oxidative stress due to mycotoxicty, immune dysfunction and a poor outcome ${ }^{[26]}$. On the other hand, Trace amount of AFP is also produced in the fetal gastrointestinal tract, kidney and placenta ${ }^{[27]}$. In this study, the mean value of AFP concentration $(\mathrm{ng} / \mathrm{ml})$ showed significant increase $(P>0.05)$ in G I and G II, this results from nephrotoxicity of patulin where, Aoki, et al. 2001 said that Serum elevation of AFP has been reported in renal cell carcinomas. AFP-producing neoplasm of the urinary tract is one case of renal pelvic carcinoma ${ }^{[28]}$. Also, the mean value of serum CEA concentration (ng/ $\mathrm{ml})$ showed highly significant increase $(P>0.001)$ in $G$ I and $G$ II. This could be due to insufficient elimination of CEA through the kidneys, dialysis membranes and peritoneum ${ }^{[29]}$. It is clearly from Table 1 that the mean value of serum M2-PK concentration $(\mathrm{ng} / \mathrm{ml})$ showed significant decrease $(\mathrm{P}>0.05)$ in $\mathrm{G}$ I and G II. It is well documented in literature that the first step during multistep carcinogenesis is the loss of the tissue-specific isoenzymes, e.g. L-PK in liver and kidney and M1-PK in brain and muscle, followed by the subsequent expression of the M2-PK isoenzyme as was demonstrated for renal cell carcinoma ${ }^{[30]}$. The impairment in renal function that revealed by these biochemical results was parallel to the histological findings. There was thickening of the glomerular and tubular basement membrane. This might result from an increase in the amount of collagen fibers secondary to their overproduction from regenerated epithelial cells. In accordance to these suggestions some authors found that reactive oxygen species (ROS) led to GBM components oxidation and changed type IV collagen formation ${ }^{[31,32]}$. Fusion of broad flat processes of podocyte led to disappearance of the slit diaphragm leading to the onset of protein uria that was manifested as hyaline casts. This could be due to direct injury to the podocyte skeleton by increased the production of ROS and decreased antioxidant levels. Moreover, this might occur with thickened GBM to compensate the increased glomerular permeability ${ }^{[33]}$. However 
some authors suggested that this fusion might be as a result of podocyte epithelial-to-mesenchymal cell transition ${ }^{[34-36]}$, found that patulin caused endoplasmic reticulum stress response and the induction of the mitochondrial apoptotic pathway in kidney cells. In accordance with this suggestion it was proved that patulin led to membranes depolarization, increased $\mathrm{Ca}^{2+}$ level and cell damage by forming adducts with thiol-containing cellular components $^{[37,38]}$, On the other hand ${ }^{[39]}$ noted that patulin caused p38 kinase and c-Jun N terminal kinase phosphorylation. However, it was found that patulin could disrupt the apoptotic mechanism $^{[40]}$. In association with these tubular changes there were some dysplastic tubules, frequent mitotic figures and high level of AFP, and CEA. This might refer to the ability of patulin to induce precancerous changes in the renal tissue ${ }^{[41]}$. In coincide to that it was proved that some apoptotic triggers are important in tumor progression as UV radiation ${ }^{[42]}$.

However, there were no significant changes in the mean value of all previous biochemical parameters, BUN, SCr, TAS, and M2-PK were observed in III (therapeutic) and IV (prophylactic) groups compared to control. This is due to the effective role of Lycium Barbarum in reducing oxidative stress induced by a chemical toxin where Lyciumbarbarum extract as effective free radical scavengers, was demonstrated and has antioxidant activity ${ }^{[43]}$. On the other hand, it has the ability for absorption or elimination of the mycotoxinand inhibiting its transformation resulting in the increase of its toxicity ${ }^{[44]}$. Lyciumbarbarum (Goji) contain pharmacologically Active constituents that offer a variety of indications that affect different organs of the body ${ }^{[45]}$.

It was proved that it could decrease the expression of CYP2E1 ${ }^{[46]}$. The improvement in the degenerative changes in the renal tubules could be due to the direct effect of the extract on DNA ${ }^{[14]}$ and cell membrane ${ }^{[47,48]}$ found that, Lyciumbarbarum could reduce diabetic nephropathy. However non-significant changes of AFP and CEA with absence of the mitotic figures and dysplastic tubules might be secondary to anticancer activity of Goji. In accordance with this suggestion it was proved that its aqueous extract could inhibit proliferation in hepatocellular cancer in rat and growth of sarcoma in mice ${ }^{[49,50]}$.

\section{Conclusion}

In Conclusion, this study has described several biochemical assays of kidney after administration of patulin mycotoxin to rats. These results add to our knowledge of one of the most important Penicillium and Aspergillus mycotoxins occurring naturally in agriculture products and it is found that treatment of rats with Goji extract ameliorated the adverse effects of mycotoxins. The results suggest that Goji extracts may be used asantioxidant and antidote for patulin in mice.

\section{References}

1. Worldwide regulations for mycotoxins in food and in feed in 2003. (2011) FAO Food and Nutrition Paper 81.

2. Betina, V. Mycotoxins: production, isolation, separation, and purification. (1984) Amsterdam: Elsevier 528.

3. Sforza, S., Dall'asta, C., Marchelli, R. Recent advances in mycotoxin determination in food and feed by hyphenated chromatographic techniques/ mass spectrometry. (2006) Mass Spectrom Rev 25(1): 54-76.

4. Ritieni, A. Patulin in Italian commercial apple products. (2003) J
Agric Food Chem 51(20): 6086-6090.

5. Majerus, P., Kapp, K. Reports on tasks for scientific cooperation, Report of experts participating in Task 3.2.8 Assessment of dietary intake of Patulin by the population of EU Member States. (2002) Brussels: SCOOP Report.

6. Speijers, G.J., Franken, M.A., Van Leeuwen, F.X. Subacute toxicity study of patulin in the rat: effects on the kidney and the gastro-intestinal tract. (1988) Food ChemToxicol 26(1): 23-30.

7. Gopalakrishnan,V.K., Sakthisekaran,D. Effect of patulin on albumin fraction of plasma proteins studied in rats.(1991) Biochem Int 25(3): 461-475.

8. Riley, R.T., Showker, J.L.The mechanism of patulin's cytotoxicity and its antioxidant activity of indoletetramic acids (1991) Toxicol Appl Pharmacol 109(1): 108-126.

9. Speijers, G.J.A., Franken, M.A.M., Van Leeuwen, F.X., et al.Subchronic oral toxicity study of patulin in the rat. (1986).

10. Devaraj, H., Suseela, R.E.,Devaraj, N. Patulintoxicosis in chicks. (1986) Curr Sci 55(19): 998-999.

11. Devaraj, H., Devaraj, N. Rat intestinal lipid changes in patulin toxicity. (1987) Indian J of Exp Biol 25(9): 637-638.

12. Kähkönen, M.P., Hopia, A.I., Vuorela, H.J., et al. Antioxidant activity of plant extracts containing phenolic compounds. (1999) J Agric Food Chem 47(10): 3954-3962.

13. Gan, L., Hua Zhang, S., Liang Yang, X., et al. Immunomodulation and antitumor activity by a polysaccharide-protein complex from Lyciumbarbarum. (2004) International Immunopharmacolology 4(4): 563-569.

14. Li, X.L., Zhou, A.G. Evaluation of the antioxidant effects of polysaccharides extracted from Lyciumbarbarum. (2007) Medicinal Chemistry Research 15: 471-482.

15. Yang Song, Baojun Xu. Diffusion Profiles of Health Beneficial Components from Goji Berry (Lyciumbarbarum) Marinated in Alcohol and Their Antioxidant Capacities as Affected by Alcohol Concentration and Steeping Time. (2013) Foods 2(1): 32-42.

16. El-Sawi,N.M., Gashlan, M.H, Younes, H.H., et al. Biochemical and histological studies on the effect of the Patulinmycotoxin on male rats' liver and treatment by crude venom extracted from jelly fish. (2012) Life Science Journal 9(4).

17. Bancroft, J.D., Gamble, M. Theory and practice of histological techniques $5^{\text {th }}$ edn (2001) London Churchill Livingstone 800.

18. Hayat, M.A.Principles and techniques of electron microscopy: biological applications $4^{\text {th }}$ edn. (2000) Cambridge University Press.

19. Corbett, J.V. Laboratory tests and diagnostic procedures with nursing diagnoses $7^{\text {th }}$ Edn. (2008) 816.

20. Gradwohl's clinical laboratory methods and diagnosis $8^{\text {th }}$ edn. (1981) Immunology 43(4): 803.

21. Kathleen D.P. Mosby's Manual of Diagnostic and Laboratory Tests $5^{\text {th }}$ edn.

22. Harfenist, E.J.,Murray, R.K. Plasma proteins, immunoglobulins, and clotting factors. (1991) In: Harper's biochemistry $22^{\text {nd }}$ Edn Appleton and Lange 611.

23. Bokhari, F., Ali, S. S. OchratoxinA (OTA) contaminated Arabian Coffee seeds: Effects on liver and kidney functions and possible protective role of Vitamin C. (2008) Advances in Biolog Rese 2(1-2): 17-25. 24. Gashlan, H.M.Biochemical studies of patulin on liver function in male albino mice. (2008) Journal of Applied Animal Research 34(1): 93-96.

25. Puel, O., Galtier, P.,Osawald, I.P. Biosynthesis and toxicological effects of patulin toxins. (2010) Toxins 2(4): 613-631.

26. Teng, R.J., Ye, Y.Z., Parks, D.A., et al. Urate produced during hypoxia protects heart proteins from peroxynitrite-mediated protein nitration. (2002) Free Rad Biol Med 33(9): 1243-1249.

27. Hong, S.M., Yu, E., Ahn H., et al. Alpha-Fetoprotein Producing Renal Cell Carcinoma. (1998) J Korean Med Sci 13(3): 321-324.

28. Ishikura, H., 1shiguro,T., Enatsu, C., et al. Hepatoid adenocarcinoma of the renal pelvis producing alpha-fetoprotein of hepatic type and 
bile pigment. (1991) Cancer 67(12): 3051-3056.

29. Huseyin Engin, Ali Borazan, Selim Aydemir, et al. Assessment of tumor markers in patients with chronic renal failure . (2007) 37(4): 143147.

30. Wechsel, H.W., Petri, E., Bichler, K.H. et al. Marker for renal cell carcinoma (RCC): the dimeric form of pyruvate kinase type M2 (Tumor M2-PK). (1999) Anticancer Res 19: 2583-2590.

31. Donovan, K.L., Davies, M., Coles, G.A., et al. Relative roles of elastase and reactive oxygen species in the degradation of human glomerular basement membrane by intact human neutrophils. (1994) Kidney Int 45: 1555-1561.

32. Riedle, B., Kerjaschki, D. Reactive oxygen species cause direct damage of Engelbreth-Holm-Swarm matrix. (1997) Am J Pathol 151(1): 215-231.

33. Ricardo, S.D., Bertram, J.F., Ryan, G.B. Reactive oxygen species in puromycinaminonucleosidenephrosis: in vitro studies. (1994) Kidney Int 45: 1057-1069.

34. Hotta, O.,Inoue, C.N., Miyabayashi, S., etal. Clinical and pathologic features of focal segmental glomerulosclerosis with mitochondrial tRNALeu (UUR) gene mutation. (2001) Kidney Int 59: 1236-1243.

35. Ronc, P. Proteinuria: is it all in the foot? (2007) J Clin Invest 117(8): 2079-2082.

36. Boussabbeh, M., Ben Salem, I., Prola, A., et al. Patulin Induces Apoptosis through ROS-Mediated Endoplasmic Reticulum Stress Pathway. (2015) Toxicol Sci 144 (2): 328-337.

37. Barhoumi, R., Burghardt, R.C. Kinetic analysis of the chronology of patulin- and gossypol-induced cytotoxicity in vitro. (1996) Fundam Appl Toxicol 30(2): 290-297.

38. Mahfoud, R., Maresca, M., Garmy, N., et al. The mycotoxinpatulin alters the barrier function of the intestinal epithelium: Mechanism of action of the toxin and protective effects of glutathione. (2002) Toxicology and Applied Pharmacolology 181: 209-218.

39. Liu, B.H., Wu, T.S., Yu,F.Y., et al. Mycotoxin Patulin Activates the p38 Kinase and JNK Signaling Pathways in Human Embryonic Kidney Cells. (2006) Toxicological Sciences 89(2): 423-430.
40. Guo, X.,Dong, Y., Yin, S., et al. Patulin induces pro-survival functions via autophagy inhibition and p62 accumulation. (2013) Cell Death and Disease 4(10): e822.

41. Aoki, K., Nakanou, I., Takashima, K., et al. A case of renal cell carcinoma producing alpha-fetoprotein. (2001) Hinyokika Kiyo 47(7): 477-480.

42. Ziegler, A., Jonason, A.S., Leffell, D.J., et al. Sunburn and p53 in the onset of skin cancer. (1994) Nature 372(6508): 773-776.

43. Luo, Q., Cai, Y., Yan, J., et al. Hypoglycemic and Hypolipidemic Effects and Antioxidant Activity of Fruit Extracts from Lyciumbarbarum. (2004) Life Sciences 76(2): 137-149.

44. Buck, W.B. Trichothecene Mycotoxins. Handbook of Natural Toxins 6 Toxicology of Plant and Fungal Compounds (1991) Marcel Deckker Inc 523-555.

45. Leung, H., Hung, A., Hui, A.C.F.,et al. Warfarin Overdose Due to the Possible Effect of LyciumbarbarumL. (2008) Food and Chemical Toxicology 46(5): 1860-1862.

46. Ha, K.T., Yoon, S.J., Choi, D.Y., et al. Protective effect of Lyciumchinense fruit on carbon tetrachloride-induced hepatotoxicity. (2005) Jounal of Ethnopharmacolology 96(3): 529-535.

47. Ma M, Lui, G., Yu, Z.,et al. Effect of the Lyciumbarbarum polysaccharides administration on blood lipid metabolism and oxidative stress of mice fed high-fat diet in vivo. (2009) Food Chem 113(4): 872-877. 48. Zhao, R., Li, Q.W., Li, J., et al. Protective effect of Lyciumbarbarum polysaccharide 4 on kidneys in streptozotocin-induced diabetic rats. (2009) Can J Physiol Pharmacol 87(9): 711-719.

49. Chao, J.C., Chiang, S.W., Wang, C.C., et al. Hot water-extracted Lyciumbarbarum and Rehmanniaglutinosa inhibit proliferation and induce apoptosis of hepatocellular carcinoma cells.(2006) World J Gastroenterol 12(28): 4478-4484.

50. Gan, L., Zhang, S.H., Yang, X.L., et al. Immunomodulation and antitumour activity by a protein complex from Lyciumbarbarum .(2004) Int Immunopharmacol 4(4): 563-569.
Online ISSN: $2377-0619$

Journal Title: International Journal Food and Nutritional Science Journal Short Name: Int J Food Nutr Sci
Ommega Online Publishers

E-mail: foodscience@ommegaonline.org Website: www.ommegaonline.org 